\title{
The Acquisition of Complex Structures: The Case of Child ESL
}

\author{
Yumiko Yamaguchi \\ Department of English Language, Tokyo Denki University, Tokyo, Japan \\ Email: yyamaguchi@cck.dendai.ac.jp
}

Received June 30 $0^{\text {th }}, 2013$; revised August $2^{\text {nd }}, 2013$; accepted August $10^{\text {th }}, 2013$

\begin{abstract}
Copyright (C) 2013 Yumiko Yamaguchi. This is an open access article distributed under the Creative Commons Attribution License, which permits unrestricted use, distribution, and reproduction in any medium, provided the original work is properly cited.
\end{abstract}

\begin{abstract}
This study examines how complex linguistic structures are acquired in child English as a second language The spontaneous speech producing by a Japanese primary school child, learning English in a naturalistic environment, was audio-recorded regularly over two years and the development of complex syntactic structures containing subordinate clauses was compared with the acquisition of other English morphosyntactic structures as represented within Processability Theory (PT) (Pienemann, 1998; Pienemann, Di Biase, \& Kawaguchi, 2005). Although PT predicts that subordination is acquired at the highest stage in processability hierarchy, the results in this longitudinal study show that some of the subordinate constructions emerge at earlier stages in child ESL acquisition.
\end{abstract}

Keywords: English as a Second Language; Complex Structures; Subordinate Clauses; Processability Theory; Primary School Child

\section{Introduction}

The development of subordinate clauses has been the focus of much language acquisition research in both first language (L1) (e.g., Diessel \& Tomasello, 2005; Kidd \& Bavin, 2002; Sheldon, 1974) and second language (L2) contexts (e.g., Doughty, 1991; Eckman, Bell, \& Nelson, 1988; Gass, 1979; Izumi, 2003; Pavesi, 1986). However, most of the previous studies are experimental and few observational studies on this issue have been conducted. While the use of English subordinate clauses in children's spontaneous speech in L1 acquisition has been examined to some extent (e.g., Bowerman, 1979; Bloom, 1991; Diessel, 2004), longitudinal studies on the development of subordinate clauses by L2 learners (e.g., Mellow, 2006; Schumann, 1980) are rare. Also, a majority of previous studies analyzed the acquisition of relative clauses in terms of noun phrase accessibility hierarchy (Keenan \& Comrie, 1977).

\section{Subordinate Clauses in English}

Basic types of English subordinate clauses include complement, relative, and adverbial clauses (e.g., Diessel, 2004; Kroeger, 2005). Complement clauses are commonly defined as subordinate clauses functioning as an argument of the matrix clause predicate. They may serve as the subject or object of the matrix clause. In child L1 studies (e.g., Diessel, 2004, Diessel \& Tomasello, 2001), object complement clauses are found to be very common in early child speech. Also, it is found that sentential complements (S-complements) marked by "that" or zero (e.g., "Ken know (that) Mary likes dogs") are the earliest complement clauses and emerge a few months after the second birthday. Wh-complements (e.g., "I wonder what John ate for lunch") and If-complements marked by "if" or "whether" (e.g., "Lisa asked me if I like pizza") are found to appear several months after the first S-complements.

Relative clauses are subordinate clauses that modify a referential expression in the matrix clauses. The modified element is called the head (or filler), and the head can be the subject, the object, an oblique, a predicate nominal, and so on. Child L1 studies (e.g., Diessel, 2004; Diessel \& Tomasello, 2000) found that the vast majority of the children's early relative constructions contain a single proposition. In particular, Diessel (2004) who observed five young children found that an average of $80 \%$ of the first ten relative clauses produced by each child is attached to the predicate nominal of a copular clause. Those constructions are called "presentational relatives" and the examples are shown as in 1) to 4). According to Diessel (2004), young children often produce infinitival and participial relative constructions containing a single proposition, as in 3) and 4) respectively.

1) That's the dog that bit me.

2) There is the girl who Tim loves.

3) This is something to eat.

4) Here's a bird chasing a cat.

This indicates that relative constructions expressing two propositions, as shown in 5) and 6), rarely appear at early stages in child $\mathrm{L} 1$ acquisition.

5) The boy who called me lives in Japan.

6) I ate the cake which Mary baked.

Regarding adverbial clauses, final adverbial clauses (e.g., "When Mary came, I was eating lunch") are found to emerge earlier than final adverbial clauses (e.g., "I washed my hands after I cleaned my room") in child L1 acquisition (e.g., Diessel, 2004). 


\section{Subordinate Clauses in Japanese}

As the L1 of the participant in this study is Japanese, this sub-section provides a brief description of Japanese subordinate clauses.

Japanese has three basic types of subordinate clauses, which are similar to those in English, such as complement clauses, relative clauses, and adverbial clauses. According to Shibatani (1991), the verb is always in the final position of the sentence in Japanese. Complement clauses are placed before the verb, as in 7), while relative clauses precede the modified noun, as in 8) and 9). Adverbial clauses are usually placed before the main clause, as in 10).

7) Ken wa [Mary ga sushi o tabeta koto] o shitteiru

"Ken knows [that Mary ate sushi]."

8) Ken wa [Mary ga dokode sushi o tabeta ka] kiita

"Ken asked Mary [where she ate sushi]."

9) Mary wa [Ken ga tukutta yuushoku ] o tabeta

"Mary ate dinner [that Ken cooked]."

10) [Mary ga kita toki] Ken wa yuushoku o tukutta

"[When Mary came], Ken cooked dinner."

\section{Processability Theory (PT)}

This study uses Processability Theory (PT) (Pienemann, 1998; Pienemann, et al., 2005) as a theoretical framework for analysing the learner's development of complex syntax. PT predicts a universal hierarchy of processing procedures, which are required for producing linguistic structures, based on Levelt's (1989) speech production model and Lexical Functional Grammar (e.g., Bresnan, 2001). According to PT, learners, at any stage of development, are able to produce only those linguistic structures which the current stage of their language processors can handle. The hypothetical hierarchy of processing procedures for morpho-syntactic development is summarized in Pienemann (1998, 2005), as shown in Table 1.

At the first stage, the learner has not developed any language-specific procedures yet. Thus, possible outcomes at this stage are single words of invariant form that do not require any processing procedure or information exchange.

The learner at the category procedure stage is assumed to become able to employ lexical form variation, such as the insertion of the affix -ed on the verb for indicating past tense and plural $-s$ marking on nouns without agreement, as in I read books.
At the phrasal procedure stage, the agreement between the head noun and its modifier in the noun phrase, as in two cats, is predicted to emerge since the information exchange between two elements in the same phrase becomes possible. In the case of languages with verb phrases, such as English, the learner is assumed to become able to assign particular verb forms with auxiliaries (e.g., is cooking vs. has cooked) at this stage ${ }^{1}$.

The learner at the S(entence)-procedure stage is assumed to become able to exchange information between different phrases. Thus, subject-verb agreement (i.e., third person singular $-s$, as in Mary likes pizza) is predicted to emerge at this stage.

Complex structures containing subordinate clauses are placed at the top of the processing hierarchy, namely at S'-procedure stage. At this stage, the learner is assumed to become able to exchange information about the values of relevant diacritic features between elements in different clauses, that is, the main and the subordinate clauses. According to PT, possible outcomes at the $S$ '-procedure stage are indirect questions, as in 11), since the learner needs to distinguish between the main clause and the subordinate clause where the question word order (i.e., where has Mary gone?) is not applied.

\section{1) I wonder where Mary has gone.}

Previous PT studies for English (e.g., Dyson, 2010; Pienemann, 1998; Sakai, 2008) reported that indirect questions were acquired later than other morpho-syntactic structures listed in processability hierarchy. However, as the acquisition of other types of subordinate constructions, such as relative clauses, has not been examined in PT, it is not clear whether indirect questions and other subordinate constructions are acquired at the same stage in processability hierarchy. Therefore, more studies are needed to investigate the developmental stages of complex structures containing various subordinate clauses.

\section{Research Questions}

In order to address the issues which remain unclear in previous ESL and PT studies, the following research questions are formulated in this study.

Q1: Are indirect questions acquired at the highest stage in ESL acquisition by a Japanese child as predicted in PT?

Q2: Does the child learner acquire indirect questions and other subordinate constructions at the same time?

Table 1.

Hypothetical hierarchy of processing procedures (after Pienemann, 2005).

\begin{tabular}{|c|c|c|c|c|c|}
\hline Procedure & t1 & t2 & t3 & t4 & t5 \\
\hline $\begin{array}{c}\text { S-Bar } \\
\text { Procedure }\end{array}$ & - & - & - & - & $\begin{array}{l}\text { inter-clausal information } \\
\text { exchange }\end{array}$ \\
\hline $\begin{array}{l}\text { Phrasal } \\
\text { Procedure }\end{array}$ & - & - & $\begin{array}{l}\text { phrasal information } \\
\text { exchange }\end{array}$ & $\begin{array}{l}\text { phrasal information } \\
\text { exchange }\end{array}$ & $\begin{array}{l}\text { phrasal information } \\
\text { exchange }\end{array}$ \\
\hline $\begin{array}{l}\text { Category } \\
\text { Procedure }\end{array}$ & - & $\begin{array}{l}\text { lexical form } \\
\text { variation }\end{array}$ & $\begin{array}{l}\text { lexical form } \\
\text { variation }\end{array}$ & $\begin{array}{l}\text { lexical form } \\
\text { variation }\end{array}$ & $\begin{array}{l}\text { lexical form } \\
\text { variation }\end{array}$ \\
\hline $\begin{array}{l}\text { Word/ } \\
\text { Lemma }\end{array}$ & $\begin{array}{l}\text { single words and } \\
\text { formulas }\end{array}$ & $\begin{array}{l}\text { single words } \\
\text { and formulas }\end{array}$ & $\begin{array}{l}\text { single words and } \\
\text { formulas }\end{array}$ & $\begin{array}{l}\text { single words and } \\
\text { formulas }\end{array}$ & single words and formulas \\
\hline
\end{tabular}

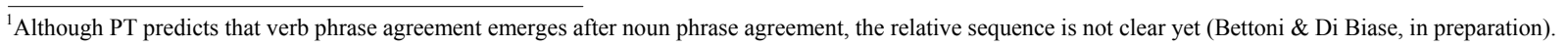




\section{Research Design}

In order to trace the way in which English subordinate clauses develop over time, a two-year longitudinal study was conducted on a Japanese primary school child learning English in Australia. Since longitudinal studies on L2 acquisition over a period of two years are rare, the current study provides a valuable resource for investigating ESL development from the beginning point of L2 learning to higher acquisitional stages.

\section{Participant}

The informant in this study is a Japanese female child, Kumika (code name). She was a Japanese monolingual until she was 5 years 7 months old. Although she participated in an English activity program instructed by a native speaker of English for 2 hours per week for 32 weeks from 4 years 10 months to 5 years 6 months old, she never received formal English instruction and had few opportunities to speak English in Japan. When she moved to Australia with her family and started attending local primary school at the age of 5 years and 7 months, her English was limited to basic words and formulaic expressions (e.g., thank you, I don't know).

\section{Data Collection Procedure}

Data collection started one month after Kumika started attending local primary school in Australia. The child's speech production in English was audio recorded regularly. Table 2 shows the amount of her exposure to English in Australia in weeks before each session.

In order to elicit the child's speech production in English, several tasks, such as picture description tasks and communication games, were utilized in this study. Each session lasted 20 to 40 minutes according to the child's motivation. All the audio-recorded sessions were transcribed.

\section{Data Analysis}

The distributional analyses of speech data were conducted for English structures listed in PT stages and other subordinate constructions. In order to examine the development of indirect questions and other types of subordinate constructions in detail, subordinate clauses appeared in the child speech production were coded based on previous observational studies (e.g., Diessel, 2004) as follows:

Complement clauses: $S$-, Wh-, If-complements

Relative clauses: Relative constructions with two propositions or with a single proposition, Presentational (e.g., there is $\sim$, this is $\sim$ ), Infinitival, or Participial relatives

Adverbial clauses: Initial or Final adverbial clauses

Then, the development of each type of subordinate clauses is compared with the acquisition of other morpho-syntactic structures listed in PT stages.

\section{Results}

The results of the distributional analyses of various subordinate clauses are presented in Table 3. The first row shows the different points in time $(\mathrm{t} 1, \mathrm{t} 2 \ldots)$ in the corpus. Note that Ifcomplements are not included in this table as they never appeared in the child corpus. The occurrences of each structure were simply counted and the total number of the occurrences was entered for each structure at each point in time. The number in brackets shows the total number of the occurrences of non-target-like relative constructions. As for Wh-complements, the number after the slash "/" indicates the contexts of $W h$ complements. For instance, "1/2" shows that the child was able to produce one target-like indirect question out of the two contexts.

As shown in Table 3, non-target-like relative constructions with a single proposition, as in 12), appeared at $\mathrm{t} 2$.

\section{2) Do you have a flower is pink?}

This structure is called "presentational amalgam construction" (Lambrecht, 1988) and is found to appear as a precursor to the presentational relative constructions at the early stage in child L1 acquisition (e.g., Diessel, 2004).

At $\mathrm{t} 3$, target-like relative constructions with a single proposition emerged in the form of infinitival relative clauses, as in 13). Then, participial relative clauses appeared at $t 4$, as in 14).

Table 2.

Kumika's exposure to English in weeks before each session.

\begin{tabular}{lllllllllllllll}
\hline Time & $\mathbf{t 1}$ & $\mathbf{t 2}$ & $\mathbf{t 3}$ & $\mathbf{t 4}$ & $\mathbf{t 5}$ & $\mathbf{t 6}$ & $\mathbf{t 7}$ & $\mathbf{t 8}$ & $\mathbf{t 9}$ & $\mathbf{t 1 0}$ & $\mathbf{t 1 1}$ & $\mathbf{t 1 2}$ & $\mathbf{t 1 3}$ & $\mathbf{t 1 4}$ \\
\hline Exposure to English (weeks) & 4 & 6 & 8 & 10 & 12 & 20 & 28 & 36 & 44 & 52 & 64 & 76 & 88 & 100 \\
\hline
\end{tabular}

Table 3.

Distribution of subordinate clauses.

\begin{tabular}{|c|c|c|c|c|c|c|c|c|c|c|c|c|c|c|}
\hline Structure/time & t1 & $\mathbf{t 2}$ & $\mathbf{t 3}$ & t4 & $\mathbf{t 5}$ & t6 & $\mathbf{t} 7$ & t8 & t9 & t10 & $\mathbf{t 1 1}$ & t12 & $\mathbf{t 1 3}$ & t14 \\
\hline$S$-comp & 0 & 0 & 0 & 0 & 0 & 1 & 1 & 2 & 2 & 1 & 4 & 2 & 1 & 2 \\
\hline$W h$-comp & 0 & 0 & 0 & 0 & 0 & 0 & $1 / 1$ & $3 / 3$ & $1 / 1$ & $1 / 1$ & $1 / 2$ & $1 / 1$ & 0 & 0 \\
\hline Relatives-two propositions & 0 & 0 & 0 & 0 & 0 & 0 & 0 & 0 & 1 & 2 & 0 & 2 & 1 & 0 \\
\hline Relatives-single proposition (with $W h$-, that, or zero) & 0 & $(8)$ & (1) & 0 & 0 & (1) & 0 & 1(1) & 4 & 2 & 4 & 5 & 2 & 2 \\
\hline (Participial relatives) & 0 & 0 & 0 & 2 & 0 & 4 & 5 & 0 & 4 & 0 & 0 & 0 & 8 & 2 \\
\hline Final ADV & 0 & 0 & 0 & 0 & 0 & 1 & 3 & 0 & 2 & 5 & 3 & 1 & 1 & 7 \\
\hline Initial ADV & 0 & 0 & 0 & 0 & 0 & 0 & 1 & 2 & 11 & 5 & 4 & 8 & 9 & 7 \\
\hline
\end{tabular}


13) We have a books to read

14) I have dog eating the doughnut

At t6, S-complements and adverbial clauses in the final position emerged at the same time, as in 15) and 16) respectively.

15) Boy think that's a bad man

16) Scooby Doo was really scary because they are going fast

At $\mathrm{t} 7$, Wh-complements in the form of indirect questions emerged, as in 17).

\section{7) Do you know what this is?}

At the same time, adverbial clauses in the initial position also emerged, as in (18). Note that " $\mathrm{xxx}$ " in brackets indicates an unintelligible word with three syllables.

\section{8) When boy sleep (xxx) he start to go out from a bottle}

At $\mathrm{t} 8$, the child started using relative pronouns in the presentational relative constructions which express a single proposition, as in 19).

19) One day there was a mother who was not scared of anything

Then, at $\mathrm{t} 9$, she finally produced relative constructions containing two propositions for the first time, as in 20).

\section{0) They have something looks like stick}

Although she omitted a relative pronoun, namely "that" in 19), more target-like relative constructions with two propositions appeared at $\mathrm{t} 10$, as in 21) and 22).

21) He got up and look at his frog that he caught yesterday

22) He saw big bunch of the bees who was chasing the dog

\section{Discussion}

The results show the child in this study produced "presentational amalgam constructions" before any of the target-like relative constructions. This is consistent with the findings in child L1 acquisition studies (e.g., Diessel, 2004) and suggests that the amalgam construction can be a precursor to the presentational relative constructions in L2 acquisition as well.

Figure 1 shows PT stages for other morpho-syntactic structures compared with emergence points for subordinate construction examined in this study.

As shown in Figure 1, the child was at stage 3, namely phrasal procedure stage, when English subordination emerged. This suggests that the child started using subordinate clauses after she acquired phrasal morphology which requires phrasal procedure. At that time, the child was able to produce relative constructions containing only one proposition. The child was still at stage 3 when S-complements and adverbial clauses in the final position emerged at $t 6$.

When the child reached stage 4, namely S-procedure stage, at t7, Wh-complements in the form of indirect questions and adverbial clauses in the initial position emerged. This indicates that indirect questions emerged at the same time when the child

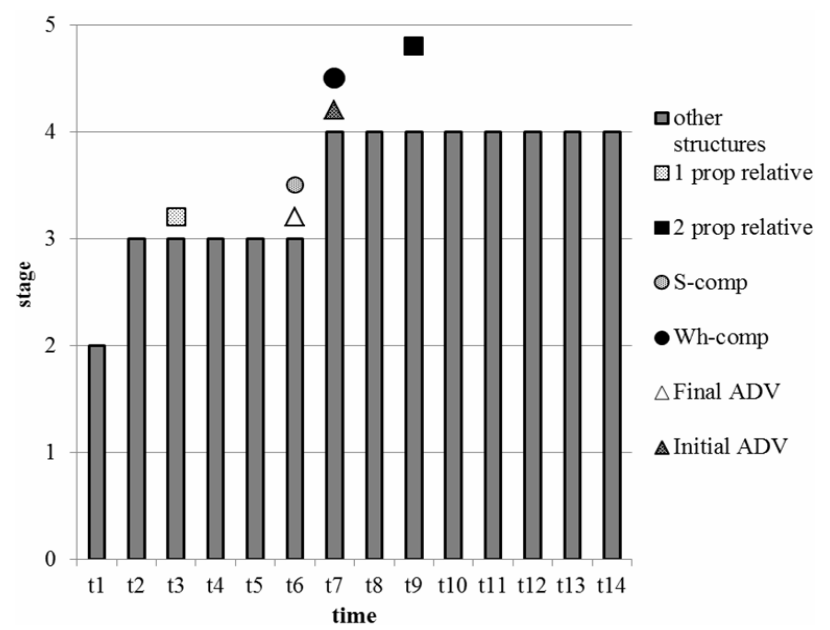

Figure 1.

Stages for other structures compared with emergence points for subordinates.

acquired inter-phrasal morphology. Thus, this finding is not compatible with the prediction in PT that the production of indirect questions requires the highest procedural skill, namely S'-procedure.

On the other hand, relative constructions containing two propositions emerged at $\mathrm{t} 9$ after she acquired other morphosyntactic structures listed in PT stages. This suggests that only relative constructions with two propositions can be considered to emerge at the highest stage in L2 acquisition.

These findings indicate that different types of subordinate constructions emerged at different stages in child ESL acquisition. In other words, indirect questions and other types of subordinate constructions, except initial adverbial clauses, are not found to be acquired at the same time. Since indirect questions were acquired when the child was at S-procedure stage, the finding in this study is not consistent with the prediction in PT that English subordination emerges at S'-procedure stage. This suggests that it may be necessary to reconsider possible outcomes at S'-procedure stage in processability hierarchy and to reformulate developmental stages by including other types of subordinate constructions.

However, it should be noted that the earlier occurrence of relative constructions with a single proposition is compatible with the findings in L1 acquisition studies. Also, final adverbial clauses are shown to develop before initial adverbial clauses as found in L1 acquisition studies. These findings suggest that English subordination develops in a similar manner in both L1 and $\mathrm{L} 2$ acquisition.

\section{Conclusion}

The results of this two-year longitudinal study of a Japanese child learner do not show support for the prediction in PT that indirect questions are acquired at the highest stage in ESL acquisition. This study also demonstrates that indirect questions and other types of subordinate constructions, except initial adverbial clauses, are not acquired at the same time. As only relative constructions expressing two propositions are found to emerge at the highest stage, it seems that the production of subordinate clauses does not always require the highest procedural skill. However, as this study examined only one Japanese pri- 


\section{Y. YAMAGUCHI}

mary school child, more research on the acquisition of complex structures including various subordinate clauses is needed in order to establish more precise developmental stages for English L2.

\section{REFERENCES}

Bettoni, C., \& Di Biase, B. (in preparation). Grammatical development in second languages: Exploring the boundaries of processability theory.

Bloom, L. (1991). Language development from two to three. Cambridge: Cambridge University Press.

Bowerman, M. (1979). The acquisition of complex sentences. In P. Fletcher, \& M. Garman (Eds.), Language acquisition: Studies in first language development (pp. 285-305). Cambridge: Cambridge University Press.

Bresnan, J. (2001). Lexical-functional syntax. Oxford: Blackwell.

Diessel, H. (2004). The acquisition of complex sentences. Cambridge: Cambridge University Press. doi:10.1017/CBO9780511486531

Diessel, H., \& Tomasello, M. (2000). The development of relative clauses in spontaneous child speech. Cognitive Linguistics, 11, 131151.

Diessel, H., \& Tomasello, M. (2001). The acquisition of finite complement clauses in English: a corpus-based analysis. Cognitive Linguistics, 12, 97-141. doi:10.1515/cogl.12.2.97

Diessel, H., \& Tomasello, M. (2005). A new look at the acquisition of relative clauses. Languages, 81, 882-906.

Doughty, C. J. (1991). Second language instruction does make a difference: Evidence from an empirical study of SL relativization. Studies in Second Language Acquisition, 13, 431-469. doi: $10.1017 / \mathrm{S} 0272263100010287$

Dyson. B. (2010). Learner language analytic methods and pedagogical implications. Australian Review of Applied Linguistics, 33, 30.130.21. doi:10.2104/aral1030

Eckman, F.R., Bell, L., \& Nelson, D. (1988). On the generalization of relative clauses instruction on the acquisition of English as a second language. Applied Linguistics, 9, 1-20. doi:10.1093/applin/9.1.1

Gass, S. (1979). Language transfer and universal grammatical relations. Language Learning, 29, 327-344. doi:10.1111/j.1467-1770.1979.tb01073.x

Izumi, S. (2003). Processing difficulty in comprehension and production of relative clauses by learners of English as a second language. Language Learning, 53, 285-323. doi:10.1111/1467-9922.00218

Keenan, E., \& Comrie, B. (1977). Noun phrase accessibility and uni- versal grammar. Linguistic Inquiry, 8, 63-99.

Kidd, E., \& Bavin, E. L. (2002). English-speaking children's comprehension of relative clauses: Evidence for general-cognitive and language-specific constraints on development. Journal of Psycholinguistic Research, 31, 599-617. doi:10.1023/A:1021265021141

Kroeger, P. R. (2005). Analyzing grammar: An introduction. Cambridge: Cambridge University Press. doi:10.1017/CBO9780511801679

Lambrecht, K. (1988). There was a farmer had a dog: Syntactic amalgams revisited. Berkeley Linguistics Society, 14, 319-339.

Levelt, W. J. M. (1989). Speaking: From intention to articulation. Cambridge, MA: The MIT Press.

Limber, J. (1973). The genesis of complex sentences. In T. E. Moore (Ed.), Cognitive development and the acquisition of language (pp. 169-185). New York: Academic Press.

Mellow, D. (2006). The emergence of second language syntax: A case study of the acquisition of relative clauses. Applied Linguistics, 27, 620-644. doi:10.1093/applin/aml031

Pavesi, M. (1986). Markedness, discoursal models, and relative clause formation in a formal and informal context. Studies in Second Language Acquisition, 8, 38-55. doi:10.1017/S0272263100005829

Pienemann, M. (1998). Language processing and second language development: Processability theory. Amsterdam/Philadelphia: John Benjamins.

Pienemann, M., Di Biase, B., \& Kawaguchi, S. (2005). Extending processability theory. In: M. Pienemann (Ed.), Cross-linguistic aspects of processability theory (pp. 199-251). Amsterdam: John Benjamins.

Pienemann, M., \& Mackey, A. (1993). An empirical study of children's ESL development and rapid profile. In P. McKay (Ed.), ESL development: Language and literacy in schools (pp. 115-259). Canberra: Commonwealth of Australia and National Languages and Literacy Institute of Australia.

Sakai, H. (2008). An analysis of Japanese university students' oral performance in English using Processability Theory. System, 36, 534 549. doi:10.1016/j.system.2008.03.002

Schumann, J. H. (1980). The acquisition of English relative clauses by second language learners. In R. C. Scarcella, \& S. Krashen (Eds.), Research in second language acquisition: Selected papers of the lost angeles second language acquisition research forum (pp. 118-131). Rowley, MA: Newbury House.

Sheldon, A. (1974). On the role of parallel function in the acquisition of relative clauses in English. Journal of Verbal Learning and Verbal Behavior, 13, 272-281. doi:10.1016/S0022-5371(74)80064-2

Shibatani, M. (1990). The languages of Japan. Cambridge: Cambridge University Press. 